\title{
Development of Basketball Learning Model Based on E-Learning and Media Applications in Faculty of Sports Sciences (FIK) Medan State University
}

\author{
Ade Ros Riza ${ }^{1, *}$ Filli Azandi ${ }^{2,}$ Mawardinur ${ }^{2}$ Nimrot Manalu ${ }^{1 .}$ \\ ${ }^{1}$ Departement of Physical Education Healt and Recreation of Faculty of Sport Science Universitas Negeri Medan, Jl. \\ Willem Iskandar Pasar V Medan Estate. \\ ${ }^{2}$ Departement of Sport Science Institute STOK Bina Guna. \\ *Corresponding author. Email: aderosriza@gmail.com
}

\begin{abstract}
This research is a development research that aims to improve learning outcomes and help in the field of sports science, especially in basketball. The media developed in the form of learning applications and basketball game scorers in the form of applications and instructional videos. The learning application contains lecture materials in each face-to-face amount in the form of lecture descriptions, video variations of learning, quizzes, and other instructions that support the online learning process. Then there is a scorer application that uses and guides in filling out the scorer in the form of an application and some examples of basketball game rules. This idea emerged when researchers felt the need to anticipate learning even though they were not face-to-face and practiced directly during the ongoing corona virus pandemic. Make it easy for students to access all lecture materials conducted online. The research method used is a quantitative approach and uses the Research \& Development (R \& D) method from Borg and Garll by developing products, testing the effectiveness of products that achieve the desired goal.
\end{abstract}

Keywords: Basketball, E-learning, Media application.

\section{INTRODUCTION}

Technological progress is currently experiencing very rapid progress, especially in today's millennial era, both in the field of science or in the field of technology which we often hear in everyday life as science and technology (Science and Technology). The development of society in all areas of life cannot be separated from the existence of science and technology. In general, there is an assumption that the mastery and application of science and technology will guarantee the progress of society. The educational process is said to be advanced and successful if we can contribute to the development of science and technology. The rapid progress of Science and Technology cannot be denied, so that various research innovations are growing rapidly. Science and technology has a fairly important role in human activities in various activities, especially in the fields of education and sports, science and technology has helped in the physical education learning process, talent search, training, and even competitions for athletes and coaches.
Basketball is one of the most popular sports in the world. Fans of all ages find basketball to be a fun, competitive, educational, entertaining and healthy sport. Individual skills such as shooting, passing, dribbling and rebounding, as well as teamwork to attack or defend are prerequisites for success in playing this sport. [1].

This study aims to determine the effectiveness of the basketball game learning application for PJKR FIK UNIMED students. Applications that are designed to describe all lecture activities in every face-to-face.

The design of the learning application media contains:

- Competency standards to be achieved in lectures

- A collection of videos of basic techniques in basketball games 
- A collection of learning variation videos that are adjusted to each lecture schedule

- A collection of match videos and referees that record events in the match

- Strategy attack and defense in the match

In a study conducted by Hiang, explained that the basketball learning curriculum that is designed in accordance with sustainable has a significant influence on technical abilities in basketball games. [2]. The learning application developed also provides opportunities for students to study independently at home even during the COVID-19 pandemic.

Teaching reform emphasizes development with students as the main focus in the learning process. Lecturers should try to allow each student to participate in the game in each semester, allow students to learn basketball skills and rules through practice and enhance student impressions. At the same time, students' selftraining allows them to strengthen their own weak points of knowledge, which helps improve their basketball skills. [3].

Aspania Dhania [4] revealed in his research that for beginner basketball players, learning or a strong foundation must be given in mastering technique before playing a match, because it is difficult for novice players to learn in a trial match to master game technique.

To be able to maximize success in learning, it is necessary to have exercises that are designed in a

Table 1. Drible basketball learning T-Test structured and sustainable manner. [5]. Variations and forms of learning must also be adjusted to the psychomotor abilities of students / students who take part in learning.

\section{METHOD}

This research is development research which is a process or steps to develop a new product or improve an existing product, which can be accounted for. This study uses a qualitative and quantitative approach and uses the Research \& Development (R\&D) development research method with the selected development design referring to the development proposed by Borg and Gall.

In this study, the author uses a research method that is suitable for the purpose of this study, namely qualitative research. The number of samples was 30 people, who came from beginner basketball players, namely students aged 17 to 19 years. The data collection used in this study is by using a test. The test that will be used is a test of the ability of the basic movement technique of basketball

\section{RESULT AND DISCUSSION}

In this study, the data analysis used is to test the effectiveness of the learning application media that has been designed. The data analysis used is a t-test of the basic techniques of playing basketball. The results of data analysis can be seen in the table below

\begin{tabular}{|c|c|c|c|c|c|}
\hline \multicolumn{6}{|c|}{ Group Statistics } \\
\hline \multicolumn{2}{|c|}{ Basketball Learning Techniques } & $\mathrm{N}$ & Mean & $\begin{array}{c}\text { Std. } \\
\text { Deviation }\end{array}$ & Std. Error Mean \\
\hline Basket & Pre-Test Drible & 30 & 65,90 & 5,45 & ,99 \\
\hline ball & Pos-Test Drible & 30 & 82,33 & 4,61 &, 84 \\
\hline Learni & & & & & \\
\hline & & & & & \\
\hline Outco & & & & & \\
\hline mes & & & & & \\
\hline
\end{tabular}

\begin{tabular}{|c|c|c|c|c|c|c|c|c|c|c|}
\hline \multicolumn{11}{|c|}{ Independent Samples Test } \\
\hline \multirow{5}{*}{$\begin{array}{l}\text { Baske } \\
\text { tball } \\
\text { Learn } \\
\text { ing } \\
\text { Outco }\end{array}$} & \multirow[b]{4}{*}{$\begin{array}{l}\text { Equal variances } \\
\text { assumed }\end{array}$} & \multicolumn{2}{|c|}{$\begin{array}{c}\text { Levene's } \\
\text { Test for } \\
\text { Equality of } \\
\text { Variances } \\
\end{array}$} & \multicolumn{7}{|c|}{ t-test for Equality of Means } \\
\hline & & \multirow[t]{2}{*}{$\mathrm{F}$} & \multirow[t]{2}{*}{ Sig. } & \multirow[t]{2}{*}{$\mathrm{t}$} & \multirow[t]{2}{*}{ Df } & \multirow[t]{2}{*}{$\begin{array}{l}\text { Sig. (2- } \\
\text { tailed) }\end{array}$} & \multirow[t]{2}{*}{$\begin{array}{c}\text { Mean } \\
\text { Difference }\end{array}$} & \multirow[t]{2}{*}{$\begin{array}{l}\text { Std. Error } \\
\text { Difference }\end{array}$} & \multicolumn{2}{|c|}{$\begin{array}{l}95 \% \text { Confidence } \\
\text { Interval of the } \\
\text { Difference }\end{array}$} \\
\hline & & & & & & & & & Lower & Upper \\
\hline & & ,727 & ,397 & $-12,602$ & 58 & ,000 & $-16,433$ & 1,304 & $\begin{array}{r}- \\
19,044\end{array}$ & 13,823 \\
\hline & $\begin{array}{l}\text { Equal variances } \\
\text { not assumed }\end{array}$ & & & $-12,602$ & 56,439 &, 000 & $-16,433$ & 1,304 & 19,045 & 13,822 \\
\hline
\end{tabular}


Based on the table above, it can be concluded that the results of the pre-test and po-test in learning the basic techniques of dribbling basketball games have a significant value. Due to the value of Sig.(2-tailed) of $0.000<0.05$, then there is a significant difference between the scores on the pre-test and the po-test. Therefore, the results of the pre-test and po-test scores in learning the basic techniques of dribbling basketball games stated that there were significant differences, these results can be seen in the Independent Samples Test table.

Table 2. Passing basketball learning T-Test

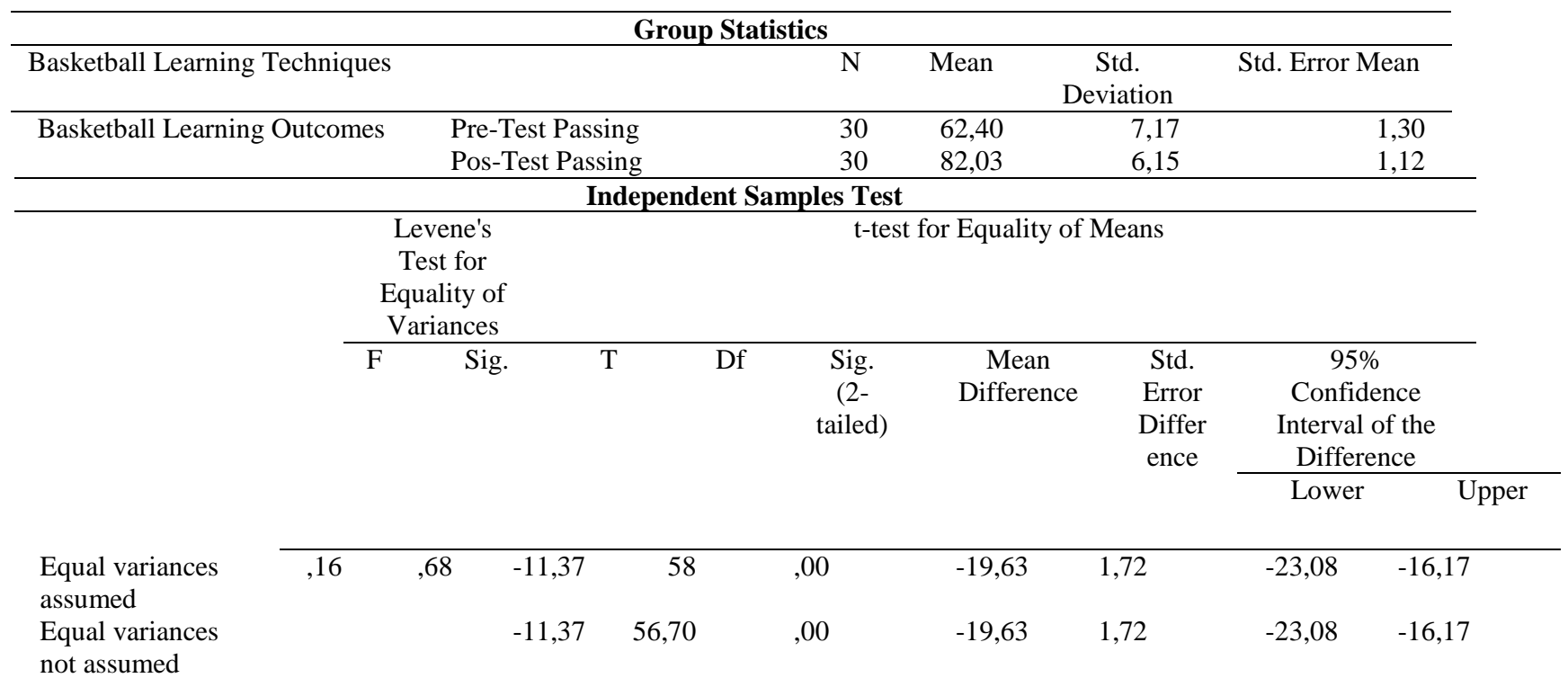

Based on the table above, it can be concluded that the results of the pre-test and po-test in learning the basic techniques of passing basketball games have a significant value. Due to the value of Sig.(2-tailed) of $0.000<0.05$, then there is a significant difference between the scores on the pre-test and the po-test. Therefore, the results of the pre-test and po-test scores in learning the basic techniques of passing basketball games stated that there were significant differences, these results can be seen in the Independent Samples Test table

Table 3. Shooting basketball learning T-Test

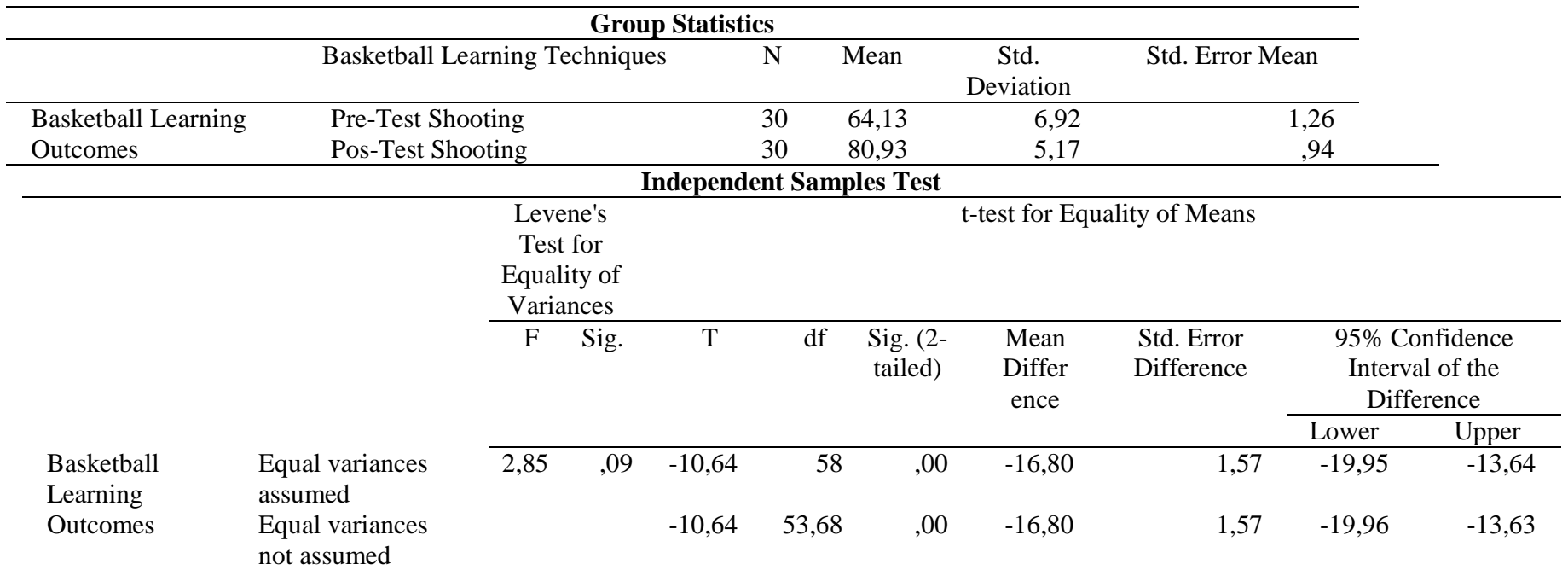

Based on the table above, it can be concluded that the results of the pre-test and po-test in learning the basic techniques of shooting basketball games have a significant value. Due to the value of Sig.(2-tailed) of 
$0.000<0.05$, then there is a significant difference between the scores on the pre-test and the po-test. Therefore, the results of the pre-test and po-test scores in learning the basic techniques of shooting basketball games stated that there were significant differences, these results can be seen in the Independent Samples Test table.

Table 4. Lay Up basketball learning T-Test

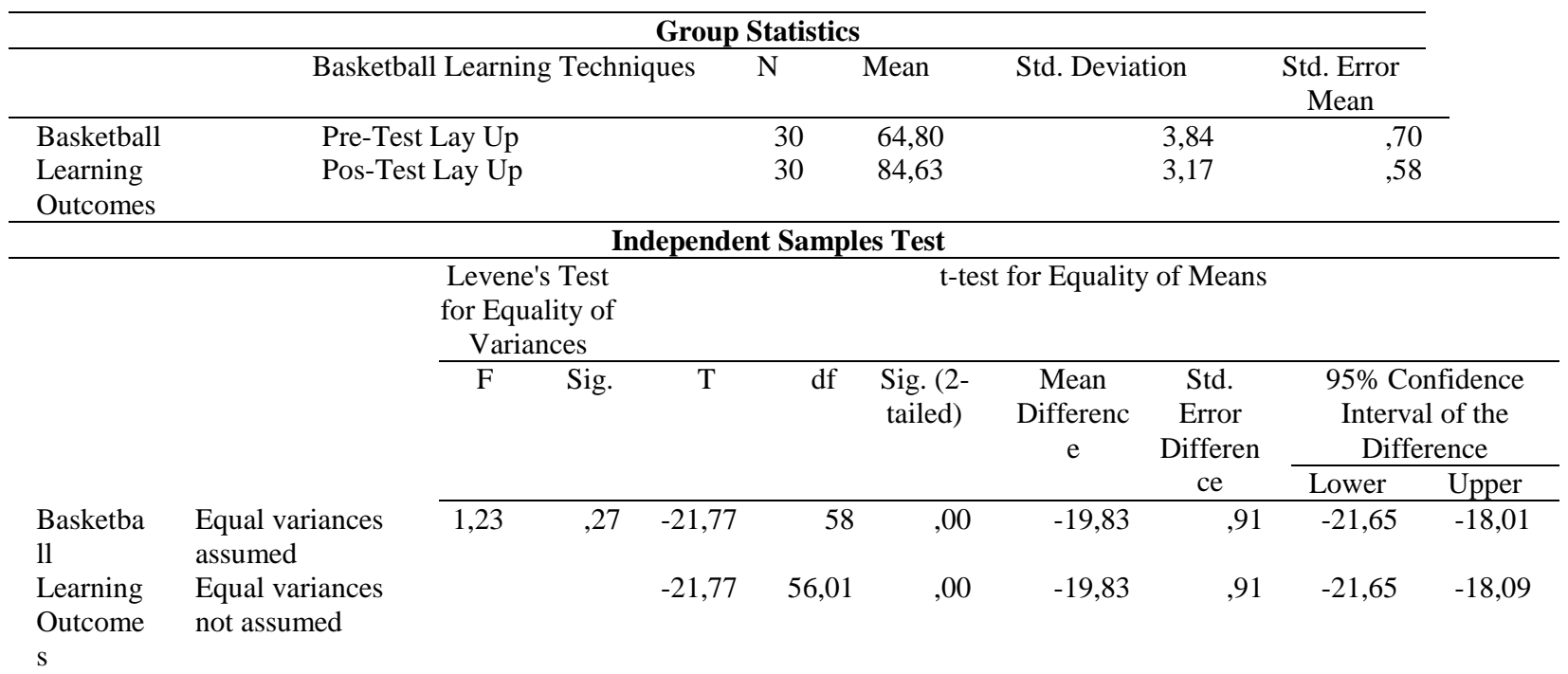

Based on the table above, it can be concluded that the results of the pre-test and po-test in learning the basic techniques of lay-up basketball games have a significant value. Due to the value of Sig. (2-tailed) of $0.000<0.05$, then there is a significant difference between the scores on the pre-test and the po-test. Therefore, the results of the pre-test and po-test scores in learning the basic techniques of s lay-up basketball games stated that there were significant differences, these results can be seen in the Independent Samples Test table.

\section{CONCLUSION}

Advanced basketball learning lectures, where one of the competencies of this lecture is that students must be able to become teachers or coaches in providing material and must be able to make or manage basketball matches. From this explanation, the researcher thinks that it is necessary to use Android application-based media technology as a student study space to gain competition management competence without having to meet face-toface or conduct match simulations in the field. The application that will be created is an Android-based basketball match scorer application that is supported by

\section{REFERENCES}

[1] Oliver, J. Dasar-dasar Bola Basket. Bandung: Pakar Raya, 2007.

[2] Hiang, T,J. Mastering Basketball with Deep Reinforcement Learning: An Integrated Curriculum
Based on the overall results of the t-test on learning basic basketball techniques, the results of the pre-tet and po-test scores have a significant value. Because all basic basketball learning techniques starting from dribbling, passing, shooting and lay-up have a Sig. (2-tailed) value of $0.000<0.05$, then there is a significant difference between the scores on the pre-test and the po-test. on learning the basic techniques of playing basketball.

video tutorials containing the use of the application, forms of match rules and how to play basketball.

From the results of the data analysis above, it can be concluded that the four basic basketball techniques, namely dribbling, passing, shooting and layup, have a significant increase in technical results, so it can be concluded that through basketball learning application media designed to suit student learning needs have a positive impact on learning. carried out both in groups, independently and online.

Training Approach. In Proc. of the 19th International Conference on Autonomous Agents and Multiagent Systems (AAMAS 2020), Auckland, New Zealand, May 9-13, 2020, IFAAMAS, 3 pages, 2020. DOI: doi/abs/10.5555/3398761.3399011. 
[3] Wen, D, Analysis of Influencing Factors and Development Trends of College Basketball Teaching Reform. International Conference on Education Science and Economic Development (ICESED 2019), Advances in Economics, Business and Management Research, 116, pp. 97-100, 2019. DOI : https://dx.doi.org/10.2991/icesed-19.2020.16

[4] Dania, A., Harvei, S. Teaching basketball to sampling-year athletes: a game-centered and situated learning perspective. Journal of Physical Education and Sport ${ }^{\circledR}$ (JPES), Vol.20 (2), Art 79 pp. 529 - 538, 2020. DOI:10.7752/jpes.2020.02079

[5] Aetano Altavilla, Global vision to understand the game situations in modern basketball. $\mathrm{J}$ ournal of Physical Education and Sport ${ }^{\circledR}$ (JPES), 14(4), Art 75, pp. $493 \quad-\quad 496,2014$. DOI:10.5901/mjss.2015.v6n3s2p227 